\title{
PEMERIKSAAN UJI KERUTAN KULIT TERSTIMULASI EUTECTIC MIXTURE OF LOCAL ANAESTHETIC (EMLA) PADA POPULASI NORMAL
}

\author{
EUTECTIC MIXTURE OF LOCAL ANAESTHETIC (EMLA) STIMULATED \\ SKIN WRINKLING TEST IN NORMAL POPULATION \\ Arthur Hendrik Philips Mawuntu, * Yoce Kurniawan, * Meilany Feronika Durry, ** Herlyani Khosama*
}

\section{ABSTRACT}

Introduction: Peripheral neuropathy (PN) could reduce life quality among the affected individuals, while early detection is difficult, apparently healthy individuals could also be affected by this disorder. Stimulated skin wrinkling by eutectic mixture of local anaesthetic test (SSW-EMLA) and brief peripheral neuropathy screening (BPNS) are simple noninvasive examination to detect $P N$.

Aims: To find out the percentage of asymptomatic neuropathy in the normal population using BPNS and SSW-EMLA.

Methods: A cross-sectional study on a population that is considered as normal who come to R.D. Kandou Hospital Manado consecutively between October 2015 and September 2016. The normal population was based on modified healthy subject criteria by Lauria et al in a study about skin neural fiber morphometry. Brief peripheral neuropathy screening and SSW-EMLA were performed in all subjects. The Chi-square or Fisher exact test were used to assess between-group differences. P-value of 0.05 was considered statistically significance.

Results: We enrolled 99 subjects, most of them were male (61.1\%) and the median age was 31 years old. Asymptomatic neuropathy was found in $25.2 \%$ of the subjects. The highest neuropathy to non-neuropathy ratio was found in the $>40$ years old group $(0,75)$. Stimulated skin wrinkling by eutectic mixture of local anaesthetic test could detect more cases compared to BPNS (24.2\% vs $7.1 \%)$ and this finding was statistically significant.

Discussion: The percentage of asymptomatic neuropathy in the normal population was $25.2 \%$ and mostly detected by SSW-EMLA compared to BPNS significantly.

Keywords: Asymptomatic neuropathy, BPNS, normal population, SSW-EMLA

\section{ABSTRAK}

Pendahuluan: Neuropati perifer dapat menurunkan kualitas hidup penderitanya, namun deteksi dini masih sulit dilakukan, padahal orang-orang yang terlihat sehat juga dapat mengalaminya. Salah satu pemeriksaan non-invasif sederhana yang dapat dilakukan adalah stimulated skin wrinkling by eutectic mixture of local anaesthetic test (SSW-EMLA) selain skrining brief peripheral neuropathy screening (BPNS) yang biasa digunakan. EMLA.

Tujuan: Mengetahui persentase neuropati asimtomatik pada populasi normal menggunakan BPNS dan SSW-

Metode: Penelitian potong lintang terhadap populasi yang dianggap normal yang berobat di Instalasi Rawat Jalan RSUP Prof. Dr. R.D. Kandou secara konsekutif antara bulan Oktober 2015 sampai September 2016. Kriteria populasi normal berdasarkan modifikasi dari kriteria subjek sehat yang dibuat oleh Lauria dkk dalam penelitian tentang morfometri serabut saraf dermal kulit manusia. Subjek dilakukan pemeriksaan BPNS dan SSW-EMLA, lalu dinilai perbedaan antar kelompok dengan uji Chi-square atau Fisher's exact. Nilai $\mathrm{p}=0,05$ dijadikan batas kemaknaan statistik.

Hasil: Terdapat 99 subjek yang sebagian besar adalah laki-laki $(61,1 \%)$ dan median usia adalah 31 tahun. Neuropati asimtomatik ditemukan pada $25,2 \%$ subjek. Rasio mengalami dan tidak mengalami neuropati tertinggi ditemukan pada kelompok usia $>40$ tahun $(0,75)$. Uji SSW-EMLA mampu mendeteksi lebih banyak kasus dibanding BPNS $(24,2 \%$ vs $7,1 \%)$ secara bermakna.

Diskusi: Didapatkan 25,2\% subjek neuropati asimtomatik pada populasi normal yang dominan ditemukan dengan uji SSW-EMLA dibandingkan BPNS secara bermakna.

Kata kunci: BPNS, neuropati asimtomatik, populasi normal, SSW-EMLA

*Bagian/KSM Neurologi FK Universitas Sam Ratulangi/RSUP Prof. Dr. R.D. Kandou, Manado; **Bagian Patologi Anatomi FK Universitas Sam Ratulangi, Manado. Korespondensi: arthur_mawuntu@yahoo.com.

\section{PENDAHULUAN}

Neuropati perifer merupakan gangguan neurologis paling sering dan menjadi salah satu tanda dari berbagai penyakit sistemik, seperti pada diabetes
mellitus(DM). Berbagai penyakit infeksi, degeneratif, autoimun, atau trauma mekanik, toksin, dan defisiensi nutrisi juga dapat menyebabkan neuropati perifer. Neuropati ini menyebabkan penurunan kualitas 
hidup yang besar bagi penderitanya, namun banyak yang sifatnya asimtomatik, terutama pada fase awal, sehingga tidak terdeteksi dan tidak dapat segera diobati. ${ }^{1}$

Neuropati asimtomatik menjadi tantangan dalam hal diagnostik, khususnya pada penyakit DM dan infeksi human immunodeficiency virus/ acquired immunodeficiency syndrome (HIV/AIDS). Pada kedua penyakit ini, neuropati perifer sangat sering ditemukan dan sangat mengganggu kualitas hidup penderitanya. Oleh karena itu diperlukan pemeriksaan diagnostik yang sensitif menemukan neuropati di fase awal, bahkan yang asimtomatik, dalam penatalaksanaan DM dan infeksi HIV. ${ }^{2-4}$

Terdapat beberapa teknik yang digunakan untuk mendeteksi neuropati berupa teknik invasif (misalnya biopsi kulit) maupun noninvasif (misalnya metode penapisan/pemeriksaan klinis, ultrasonografi saraf, pemeriksaan elektroneurografi/ENG, dan sebagainya). Biopsi kulit menilai keadaan serabut saraf kecil dengan menghitung densitas serabut saraf epidermis, sehingga dianggap sebagai alat diagnostik utama. Namun biopsi membutuhkan keahlian, metode pemrosesan jaringan, dan peralatan optik khusus untuk mendapatkan hasil yang dapat dipercaya. Oleh karena itu, teknik noninvasif lebih umum digunakan, seperti pemeriksaan refleks vasokonstriktor kulit, ultrasonografi saraf, ENG, dan penapisan neuropati perifer ringkas (brief peripheral neuropathy screening/BPNS)..$^{5-8}$

Di RSUP Prof. Dr. R.D. Kandou, Manado, BPNS merupakan metode yang paling sering digunakan, karena terjangkau, cepat, dan mudah, sehingga cocok digunakan di daerah-daerah dengan sumber daya terbatas. Skrining ini awalnya dikembangkan untuk neuropati perifer pada pasien HIV/AIDS oleh AIDS Clinical Trial Group (ACTG) tahun 2010. Sistem yang digunakan meliputi skoring penilaian gambaran subjektif dan objektif neuropati untuk menentukan kemungkinan adanya neuropati perifer. Spesifisitas BPNS cukup tinggi (sekitar 90\%) dengan nilai duga positif $72 \%$, namun sensitivitasnya rendah (sekitar 49\%). ${ }^{9}$

Pemeriksaan non-invasif lain yang mudah dilakukan adalah uji kerutan kulit terstimulasi (stimulated skin wrinkling/SSW) yang mengacu pada undulasi-undulasi di permukaan kulit yang bersifat sementara, sekitar 5-30 menit setelah kulit terendam air atau dipapar dengan campuran anestetik lokal eutektik (eutectic mixture of local anesthetics/ EMLA), atau disebut juga SSW-EMLA. Kerutan ini tejadi sebagai akibat dari vasokonstriksi kulit tanpa rambut yang diperantarai oleh serabut saraf simpatetik pascaganglionik. Sebagai tes, SSW dapat menjadi metode sederhana untuk menilai fungsi serabut saraf kecil. Terdapat korelasi antara SSW dengan densitas serabut saraf epidermis epidermal nerve fiber/EDNF pada pasien dengan neuropati sensorik. ${ }^{10-12}$

Suatu penelitian di Singapura membandingkan sensitivitas SSW-EMLA dengan metode lain guna mendeteksi neuropati perifer diabetes. Dari penelitian tersebut didapatkan sensitivitas SSW-EMLA adalah $81,3 \%$ dan spesifisitasnya $67 \%$, dengan menggunakan pemeriksaan ENG sebagai standar. Skala penilaiannya diperlihatkan pada Gambar 1 . Kesepakatan antar pemeriksanya juga tinggi dengan

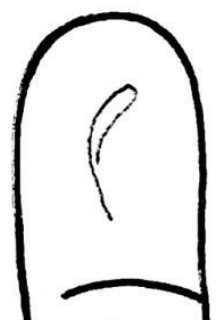

A

Derajat 0: tidak ada kerutan

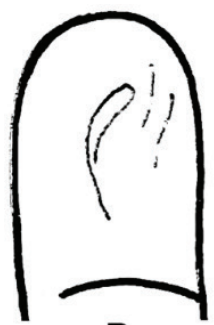

B

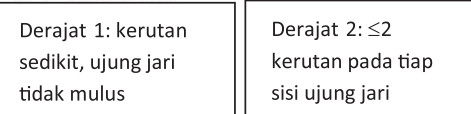

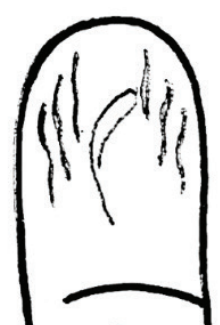

D

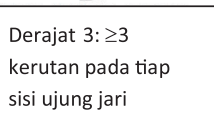

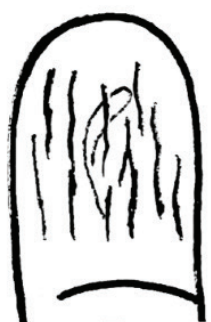

E

Derajat 4:

ujung jari mengerut

seluruhnya

Gambar 1. Skala Keriput Kulit

Dimodifikasi dari Ng dkk (2013) ${ }^{8}$ 
nilai $\kappa \quad 0,91$ untuk tangan kanan dan 0,82 untuk tangan kiri. ${ }^{13}$

Penelitian Verawati dkk di Jakarta pada penderita lepra multibasilar juga menemukan sensitivitas SSW-EMLA untuk mendeteksi neuropati otonom sebesar $95,7 \%$, spesifisitas $51,1 \%$, dan nilai duga positif $48,9 \%$ jika dibandingkan dengan pemeriksaan sudoscan. ${ }^{14}$

Sejauh ini belum ditemukan kriteria yang memuaskan terkait populasi normal yang mengalami neuropati asimtomatik. Oleh karena itu, penelitian ini mengikuti kriteria subjek sehat menurut Lauria dkk yang membuat kriteria untuk meneliti morfometrik serabut saraf intradermal manusia. ${ }^{15}$

\section{TUJUAN}

Untuk mengetahui persentase neuropati asimtomatik pada populasi berdasarkan pemeriksaan BPNS dan SSW-EMLA serta karakteristik klinisnya.

\section{METODE}

Penelitian potong lintang terhadap populasi yang dianggap normal yang berobat di Instalasi Rawat Jalan RSUP Prof. Dr. R.D. Kandou secara konsekutif antara bulan Oktober 2015 sampai September 2016. Kriteria populasi normal berdasarkan modifikasi dari kriteria subjek sehat yang dibuat oleh Lauria dkk dalam penelitian tentang morfometri serabut saraf dermal kulit manusia. Kriteria tersebut secara singkat adalah tidak memiliki kelainan pada pemeriksaan neurologis, tidak memiliki riwayat $\mathrm{DM}$, infeksi hepatitis $\mathrm{B}$ atau $\mathrm{C}$, dan defisiensi vitamin B12, tidak menggunakan obat-obat neurotoksik atau kemoterapi, bukan pecandu alkohol, tidak ada riwayat trauma saraf tepi, dan tidak ada faktor risiko HIV. ${ }^{15}$

Kriteria inklusi adalah ras Asia, berusia antara 18-60 tahun, tidak memiliki keluhan neuropati, radikulopati, atau mielopati, dan bersedia diikutsertakan dalam penelitian. Adapun kriteria eksklusi adalah memiliki riwayat penyakit sistemik mencakup terinfeksi HIV, anemia, DM, penyakit tiroid, uremia, penyakit hati, dan keganasan; mengkonsumsi obat-obat kemoterapi, statin, amiodaron, dan takrolimus $>7$ hari; memiliki pekerjaan menggunakan tangan/lengan secara repetitif/ bertenaga, seperti pekerja kasar/buruh kasar yang dapat mengganggu pemeriksaan, memiliki kelainan bawaan/pernah mengalami patah tulang atau cedera lainnya pada lengan dan tungkai yang dapat mengganggu pemeriksaan, memiliki riwayat penyakit reumatik/penyakit sendi degeneratif pada lengan/tangan yang dapat mengganggu pemeriksaan; memiliki penyakit vaskular perifer dan/atau respons vaskular abnormal seperti fenomena Raynaud; serta memiliki luka terbuka di daerah aplikasi krim EMLA.

Pemenuhan kriteria inklusi dan eksklusi dibuat berdasarkan hasil pemeriksaan klinis dan penunjang di rekam medis. Status HIV negatif dibuat berdasarkan hasil tes cepat HIV yang negatif pada voluntary consultation and testing (VCT) yang telah disetujui subjek. Status tidak menyandang DM dibuat dengan tidak ditemukannya gejala DM dan pemeriksaan glukosa darah sewaktu dan dua jam setelah makan yang normal. Subjek dinyatakan mengalami neuropati asimtomatik jika tidak memiliki keluhan subjektif neuropati, namun hasil BPNS dan/ atau SSW-EMLA tidak normal.

Penelitian ini telah mendapatkan ijin etik dari Unit Penelitian Kesehatan Terpadu RSUP Prof. Dr. R.D. Kandou tahun 2016. Semua subjek menjalani pemeriksaan fisik umum, antropometrik (untuk mengetahui berat badan/BB, tinggi badan/TB, dan indeks massa tubuh/IMT), dan neurologis (ketajaman penglihatan, fungsi nervus-nervus kranialis, kekuatan dan tonus otot, refleks-refleks, dan fungsi sensorik).

Subjek menjalani pemeriksaan BPNS lalu SSW-EMLA dengan jeda waktu 30 menit dan oleh pemeriksa yang berbeda. Pemeriksaan BPNS dan SSW-EMLA tersebut dilakukan oleh beberapa dokter residen neurologi yang telah dilatih oleh peneliti. Pemeriksaan SSW-EMLA menggunakan krim EMLA $^{\circledR} 5 \%$ (lidocaine 2,5\% and prilocaine 2,5\%, AstraZeneca), plastik pembungkus makanan Cling Wrap ${ }^{\circledR}$, pengukur waktu, dan kamera digital single lens reflex (DSLR) Nikon D3000 ${ }^{\circledR}$. Untuk pemeriksaan BPNS digunakan garpu tala $128 \mathrm{~Hz}$ untuk mengukur vibrasi, palu refleks untuk mengukur refleks tendon Achilles, dan formulir pemeriksaan BPNS. 
Protokol pemeriksaan BPNS diadopsi dari protokol ACTG tahun 2010. Ada dua komponen pemeriksaan yang dibuat: subjektif dan objektif. Pada awalnya, subjek diperiksa untuk komponen subjektif yang mencakup anamnesis tentang nyeri, pegal, atau rasa terbakar di kaki atau tangan, rasa seperti tertusuk jarum atau paku di kaki atau tangan, atau rasa baal di kaki atau tangan. Jika subjek mengatakan tidak ada keluhan, pemeriksa menanyakan lagi jika subjek pernah merasakan keluhan-keluhan tadi sebelumnya. Komponen ini seharusnya normal jika subjek telah dianggap layak mengikuti penelitian. ${ }^{9}$

Setelah penilaian komponen subjektif, dilakukan pemeriksaan dua komponen objektif. Pemeriksaan pertama adalah tes vibrasi pada sendi interfalang distal ibu jari kedua kaki menggunakan garpu tala $128 \mathrm{~Hz}$. Garpu tala digetarkan lalu ditempelkan pada sendi interfalang distal ibu jari setiap kaki. Selanjutnya dihitung lamanya subjek dapat merasakan adanya getaran di masing-masing kaki.

Pemeriksaan kedua adalah tes refleks tendon dalam pada tendon Achilles kedua kaki menggunakan palu refleks. Dinilai kekuatan respons kontraksi reflektorik dari otot gastroknemius masing-masing tungkai setelah pengetukan tendon Achilles dengan palu refleks. Metode "reinforcement" dengan manuver Jendrassik digunakan jika ditemukan refleks awal kurang atau tidak ada. ${ }^{9}$ Hasil pemeriksaan ini kemudian diterjemahkan ke dalam suatu skor sesuai protokol ACTG. Jika komponen subjektif normal tetapi ditemukan hasil positif untuk kedua komponen objektif maka subjek dianggap memiliki neuropati asimtomatik menurut pemeriksaan BPNS. ${ }^{9}$
Pada pemeriksaan SSW-EMLA, digunakan modifikasi metode Ng dkk. Awalnya, kedua tangan subjek dicuci dengan sabun dan air lalu dikeringkan. Peneliti lalu menilai penampakan awal jari-jari tangan dan dipotret sebelum pemberian krim EMLA yang tidak terlihat adanya kerutan (Gambar 2a). Krim EMLA dibalurkan secara tebal menutupi segmen distal jari II, III, dan IV tangan kanan dan kiri. Setiap jari tadi kemudian dibalut dengan plastik pembungkus dan disegel dengan selotip kulit. Setelah pemberian krim EMLA, subjek diminta untuk menunggu 30 menit dan menjaga agar kedua tangannya tetap kering dan bersih. Subjek tidak boleh makan, minum, dan merokok selang periode menunggu. Jika balutan bocor maka subjek menunggu lagi satu jam dan seluruh prosedur diulang dari awal. ${ }^{13}$

Setelah waktu 30 menit selesai, peneliti membuka balutan dan mengamati timbulnya keriput di ujung-ujung jari tadi (Gambar 2A). Penampakan ujung jari dibandingkan dengan skala yang diperlihatkan oleh Gambar 1 dan dihitung skornya. Gradasi keriput untuk jari II, III, dan IV dihitung dan dibuat rata-ratanya untuk setiap tangan. Perbedaan $\geq 3$ angka per tangan (atau $>1$ angka per jari) dianggap sebagai cut-off atau skor yang berbeda. Stimulated skin wrinkling by eutectic mixture of local anaesthetic dianggap normal jika skor keriput total setiap tangan $<9$ (Gambar 2B). ${ }^{13}$

Analisis statistik dilakukan menggunakan program Statistical Package for the Social Science $\left(\mathrm{SPSS}^{\circledR}\right)$ versi 22. Analisis bivariat dibuat untuk variabel bebas jenis kelamin, usia, pendidikan, dan indeks massa tubuh (IMT), dengan adanya neuropati asimtomatik sebagai variabel terikat.

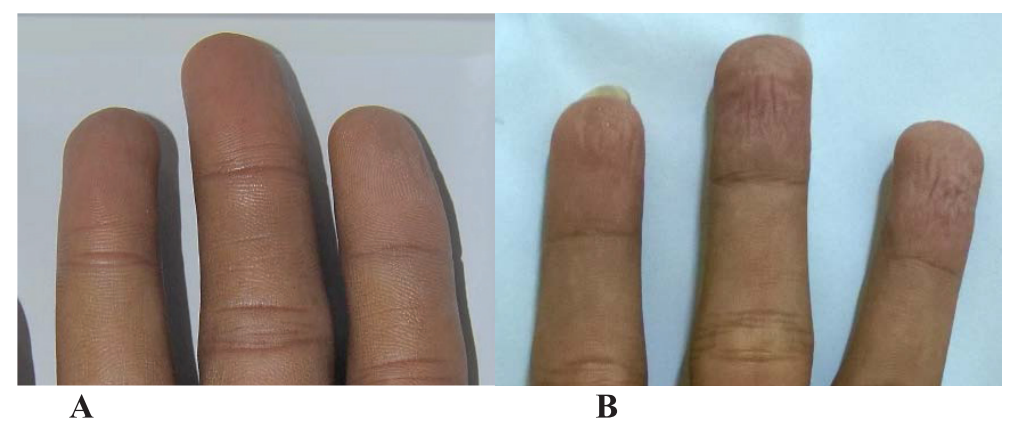

Gambar 2. Contoh Hasil Pemeriksaan Pasca Pemberian Krim EMLA pada Tes SSW-EMLA

A: Skor $2+2+3=7$, rerata $=2,3$ (abnormal); B: Skor $4+4+4=12$, rerata 4 (normal). 
Untuk menganalisis kemaknaan antar kelompok digunakan uji kai kuadrat atau uji Fisher exact (untuk variabel nonparametrik). Nilai $\mathrm{p}=0,05$ dijadikan batas kemaknaan statistik.

\section{HASIL}

Didapatkan 99 subjek yang layak mengikuti penelitian dengan mayoritas laki-laki (61,6\%) berusia 30-40 tahun (52,5\%), berpendidikan $>9$ tahun $(89,9 \%)$, median IMT 22,2 $( \pm 2,71)$.

Hasil pemeriksaan BPNS yang positif ditemukan pada 7 subjek $(7,1 \%)$ dan yang positif pada pemeriksaan SSW-EMLA sebanyak 23 subjek (23,2\%). Satu subjek memiliki hasil BPNS positif meski SSW-EMLA-nya negatif. Dengan demikian, terdapat 24 orang subjek $(24,2 \%)$ yang mengalami neuropati asimtomatik (Tabel 1). Gambar 2 memperlihatkan dua contoh foto jari-jari subjek setelah pemberian krim EMLA pada tes SSW-EMLA. Gambar 2A adalah foto subjek dengan hasil tes abnormal dan Gambar 2 B dengan hasil tes normal.

Tabel 1. Hasil Pemeriksaan Neuropati $(\mathbf{n}=99)$

\begin{tabular}{lccccc}
\hline \multirow{2}{*}{ SSW-EMLA } & \multicolumn{2}{c}{ BPNS } & & \multirow{2}{*}{ Total } & p \\
\cline { 2 - 3 } & Abnormal & Normal & & \\
\hline Abnormal & 6 & 17 & 23 & \\
Normal & 1 & 75 & 76 & $<0,001$ \\
Total & 7 & 92 & 99 & \\
\hline
\end{tabular}

Tidak terdapat adanya perbedaan yang bermakna antara jenis kelamin, usia, pendidikan, dan IMT dengan kejadian neuropati asimtomatik baik untuk variabel kategorik (Tabel 2) maupun variabel numerik (Tabel 3).
Tabel 2. Karakteristik Kategorik Subjek Berdasarkan Neuropati Asimtomatik (n=99)

\begin{tabular}{|c|c|c|c|c|}
\hline \multirow{3}{*}{ Variabel } & \multicolumn{3}{|c|}{ Neuropati Asimtomatik } & \multirow{3}{*}{$\mathbf{p}$} \\
\hline & Tidak & Ya & Total & \\
\hline & n (\%) & n (\%) & n (\%) & \\
\hline \multicolumn{5}{|l|}{ Jenis Kelamin } \\
\hline - Laki-laki & $46(47,5)$ & $15(14,1)$ & $61(61,6)$ & \multirow{2}{*}{0,7} \\
\hline - Perempuan & $28(28,3)$ & $10(10,1)$ & $38(38,4)$ & \\
\hline \multicolumn{5}{|l|}{ Usia } \\
\hline - $<30$ tahun & $26(26,3)$ & $7(7,1)$ & $33(33,4)$ & \multirow{3}{*}{0,75} \\
\hline $\begin{array}{l}30-40 \\
\text { tahun }\end{array}$ & $40(40,3)$ & $12(12,1)$ & $52(52,4)$ & \\
\hline - $>40$ tahun & $8(8,1)$ & $6(6,1)$ & $14(14,2)$ & \\
\hline \multicolumn{5}{|l|}{ Pendidikan } \\
\hline - $\leq 9$ tahun & $7(7,1)$ & $3(3,0)$ & $10(10,1)$ & \multirow{2}{*}{1,00} \\
\hline - $>9$ tahun & $67(67,7)$ & $22(22,2)$ & $89(89,9)$ & \\
\hline \multicolumn{5}{|c|}{ Indeks Massa Tubuh $\left(\mathrm{kg} / \mathrm{m}^{2}\right)$} \\
\hline - $\quad<18,5$ & $1(1,0)$ & $1(1,0)$ & $2(2,0)$ & \multirow{2}{*}{0,39} \\
\hline - $\geq 18,5$ & $97(98,0)$ & 0 & $97(98,0)$ & \\
\hline
\end{tabular}

\section{PEMBAHASAN}

Dalam penelitian ini didapatkan persentase neuropati asimtomatik yang cukup tinggi, yaitu $24,2 \%$ sebab beberapa penelitian menemukan angka neuropati asimtomatik berkisar $10-31 \%$ pada pasien dengan penyakit yang berisiko tinggi mengalami neuropati perifer seperti HIV dan diabetes mellitus. ${ }^{4-5,16}$ Hal ini diperkirakan berhubungan dengan proses penuaan karena ada kecenderungan meningkat menurut usia. Namun tingginya persentase ini menarik karena deteksi dini neuropati secara klinis sulit dilakukan padahal deteksi dini membuka peluang intervensi terapi yang lebih awal dan akan memperbaiki prognosis pada sebagian kasus.

Tabel 3. Karakteristik Numerik Subjek Berdasarkan Neuropati Asimtomatik (n=99)

\begin{tabular}{|c|c|c|c|c|c|c|c|}
\hline \multirow{3}{*}{ Variabel } & \multicolumn{6}{|c|}{ Neuropati Asimtomatik } & \multirow{3}{*}{$\mathbf{p}$} \\
\hline & \multicolumn{2}{|c|}{ Tidak } & \multicolumn{2}{|c|}{ Ya } & \multicolumn{2}{|c|}{ Total } & \\
\hline & $\begin{array}{l}\text { Rerata } \\
\text { (SD) }\end{array}$ & $\begin{array}{c}\text { Median } \\
\text { (Rentang) }\end{array}$ & $\begin{array}{l}\text { Rerata } \\
\text { (SD) }\end{array}$ & $\begin{array}{c}\text { Median } \\
\text { (Rentang) }\end{array}$ & $\begin{array}{l}\text { Rerata } \\
\text { (SD) }\end{array}$ & $\begin{array}{c}\text { Median } \\
\text { (Rentang) }\end{array}$ & \\
\hline Rerata usia (tahun) & $\begin{array}{c}31,6 \\
(8,51)\end{array}$ & $\begin{array}{c}31,0 \\
(19-59)\end{array}$ & $\begin{array}{c}35,7 \\
(11,6)\end{array}$ & $\begin{array}{c}35,5 \\
(21-59)\end{array}$ & $32,6(9,45)$ & $\begin{array}{c}31,0 \\
(19-59)\end{array}$ & 0,14 \\
\hline Rerata pendidikan (tahun) & $\begin{array}{c}15,2 \\
(2,83)\end{array}$ & $\begin{array}{c}16,0 \\
(9-18)\end{array}$ & $\begin{array}{l}14,8 \\
(2,6)\end{array}$ & $\begin{array}{c}16,0 \\
(9-18)\end{array}$ & $15,1(2,77)$ & $\begin{array}{c}16,0 \\
(9-18)\end{array}$ & 0,78 \\
\hline Rerata IMT $\left(\mathrm{kg} / \mathrm{m}^{2}\right)$ & $\begin{array}{c}22,2 \\
(2,81)\end{array}$ & $\begin{array}{c}21,8 \\
(18,0-28,7)\end{array}$ & $\begin{array}{c}22,0 \\
(2,42)\end{array}$ & $\begin{array}{c}21,7 \\
(18,0-28,9)\end{array}$ & $22,2(2,71)$ & $\begin{array}{c}21,8 \\
(18,0-28,9)\end{array}$ & 0,97 \\
\hline
\end{tabular}

SD: standar deviasi; IMT: indeks massa tubuh. 
Sulitnya deteksi dini neuropati mungkin disebabkan karena pemeriksaan yang digunakan kebanyakan memeriksa serabut saraf besar. Secara umum serabut saraf kecil lebih dulu terganggu daripada serabut saraf besar, dan pada tahap awal gangguan pada serabut saraf kecil kebanyakan bersifat subklinis. Pemeriksaan BPNS yang digunakan sebagai pembanding dalam penelitian ini, seperti yang telah disebutkan sebelumnya, memiliki sensitivitas yang rendah. Di lain pihak, pemeriksaan SSW-EMLA memeriksa fungsi serabut saraf kecil (komponen simpatetik) di kulit tanpa rambut. Hal ini menjelaskan mengapa pemeriksaan SSW-EMLA dapat mendeteksi neuropati lebih awal. ${ }^{1,13-14}$

Selain itu, pemeriksaan SSW-EMLA menemukan lebih banyak abnormalitas dibanding BPNS. Hal ini sesuai dengan temuan nilai diagnostik SSW-EMLA untuk mendeteksi neuropati perifer pada kasus DM dan lepra. ${ }^{13-14}$ Dengan demikian SSW-EMLA dapat menjadi salah satu kandidat pemeriksaan penapis neuropati perifer pada berbagai penyakit yang berpotensi menyebabkan neuropati.

Hubungan antara jenis kelamin dengan neuropati asimtomatik tidak jelas ditemukan dalam penelitian ini. Penelitian Bansal dkk tentang neuropati DM di India menemukan perempuan memang lebih banyak terkena neuropati perifer DM daripada lakilaki, namun tidak bermakna secara statistik. Evans dkk pada pasien HIV di Amerika Serikat juga tidak menemukan hubungan yang bermakna antara jenis kelamin dan kejadian neuropati. ${ }^{6,17}$

Pada penelitian ini, usia $>40$ tahun memiliki rasio mengalami dan tidak mengalami neuropati asimtomatik tertinggi $(0,75)$ dan rasio ini meningkat menurut peningkatan kelompok usia. Meskipun terlihat ada kecenderungan meningkat menurut usia, perbedaan ini tidak bermakna secara statistik. Padahal diketahui bahwa faktor usia memengaruhi angka kejadian neuropati perifer. Timbulnya neuropati dianggap sebagai bagian dari suatu proses penuaan. Selain itu, berbagai kondisi pada usia tua, seperti: DM, alkoholisme, defisiensi nutrisi, infeksi, keganasan maupun kelainan autoimun memang dapat memengaruhi kualitas fungsional saraf yang mengakibatkan neuropati. ${ }^{1,16}$ Dibutuhkan penelitian lanjutan dengan sampel yang lebih besar untuk menguji hubungan neuropati asimtomatik dengan usia.

Terdapat beberapa kelemahan dalam penelitian ini. Kriteria normal memang masih memiliki kelemahan karena beberapa hal. Subjek mengunjungi instalasi rawat jalan untuk alasan kesehatan lain seperti nyeri kepala, vertigo vestibular perifer, atau penyakit lain, sehingga sebenarnya tetap memiliki masalah kesehatan. Telusur rekam medis dan pemeriksaan klinis juga harus diakui tidak dapat memberikan informasi medis secara menyeluruh. Walaupun demikian, kami mampu menyingkirkan kriteria eksklusi penting seperti diagnosis DM dan HIV menggunakan pemeriksaan klinis dan penunjang standar yang sesuai untuk setiap penyakit.

Dibutuhkan suatu penelitian dengan desain uji diagnostik untuk mengonfirmasi besarnya temuan neuropati asimtomatik yang kami temukan. Pada penelitian ini pemeriksaan hanya dilakukan satu orang untuk setiap tes. Namun pada penelitian $\mathrm{Ng}$ $\mathrm{dkk}$, interrater agreement pada metode ini cukup tinggi. ${ }^{13}$ Kelemahan lain adalah masalah standar nilai. Standar nilai SSW-EMLA menggunakan penelitian pada neuropati DM. Penulis memang belum menemukan penelitian SSW-EMLA untuk neuropati lainnya, sehingga digunakan standar nilai pada neuropati DM.

Penelitian ini baru merupakan penelitian potong lintang sehingga hubungan variabel-variabel yang diteliti terhadap waktu tidak dapat diteliti dengan baik. Perlu ada penelitian lanjutan dengan desain kohort untuk melihat hubungan yang lebih kuat dengan melihat perubahan variabel-variabel terhadap waktu.

\section{KESIMPULAN}

Persentase neuropati asimtomatik pada populasi normal di Manado adalah 25,2\%. Rasio mengalami dan tidak mengalami neuropati asimtomatik di Manado tertinggi ditemukan usia $>40$ tahun. Pemeriksaan SSW-EMLA lebih banyak menemukan neuropati asimtomatik dibanding BPNS. 


\section{DAFTAR PUSTAKA}

1. Watson JC, Dyck PJB. Peripheral neuropathy: a practical approach to diagnosis and symptom management. Mayo Clin Proc. 2015;90(7):940-51.

2. Schutz SG, Robinson-Papp J. HIV-related neuropathy: current perspectives. HIV/AIDS-Res and Palliative Care. 2013;5:243-51.

3. Dubey TN, Raghuvanshi SS, Sharma H, Saxena R. HIV neuropathy in pre-HAART patients and it's correlation with risk factors in Central India. Neurology India. 2013;61(5):478-80.

4. Simpson DM, Kitch D, Evans SR, McArthur JC, Asmuth DM, Cohen B, dkk. HIV neuropathy natural history cohort study: assessment measures and risk factors. Neurology. 2006;66:1679-87.

5. Ellis RJ, Evans SR, Clifford DB, Moo LR, McArthur JC, Collier AC, dkk. Clinical validation of the NeuroScreen. J Neurovirol. 2005;11:503-11.

6. Evans SR, Ellis RJ, Chen H, Tzu MY, Lee AJ, Schifitto G, dkk. Peripheral neuropathy in HIV: prevalence and risk factors. AIDS. 2011;25(7):919-28.

7. Merola A, Rosso M, Romagnolo A, Peci E, Cocito D. Peripheral nerve ultrasonography in chronic inflammatory demyelinating polyradiculoneuropathy and multifical motor neuropathy: correlations with clinical and neurophysiological data. Neurol Res Intl. 2016:2016:9478593.

8. Padua L, Granata GI, Sabatelli M, Inghilleri M, Lucchetta M, Luigetti MA, dkk. Heterogeneity of root and nerve ultrasound pattern in CIDP patients. Clin Neurophysiol. 2014;125(1):160-5.

9. NIAID. ACTG brief peripheral neuropathy screening tools. US Departement of Veteran Affairs [serial online]. 2010 [diunduh 10 Februari 2014]. Tersedia dari: US Departement of Veteran Affairs.

10. Wilder-Smith EP, Guo Y, Chow A. Stimulated skin wrinkling for predicting intraepidermal nerve fibre density. Clin Neurophysiol. 2009;120:953-8.

11. Wilder-Smith EP, Chow A. Water immersion and EMLA cause similar digit skin wrinkling and vasoconstriction. Microvasc Res. 2003;66:68-72.

12. Teoh H, Chow A, Wilder-Smith EP. Skin wrinkling for diagnosing small fibre neuropathy: comparison with epidermal nerve density and sympathetic skin response. J Neurol Neurosurg Psych. 2008;79:835-7.

13. Ng KWP, Ong JJY, Nyein TDN, Liang S, Chan YC, Lee KO, dkk. EMLA-induced skin wrinkling for the detection of diabetic neuropathy. Front Neurol. 2013;4(126):1-7.

14. Verawati V, Estiasari R, Imran D. Sensitivitas dan spesifisitas pemeriksaan stimulated skin wrinkle terhadap sudoscan dalam mendeteksi neuropati otonom pada kusta multibasiler [tesis]. Depok: Universitas Indonesia; 2015.

15. Lauria G, Cazzato D, Porretta-Serapiglia C, CasanovaMolla J, Taiana M, Penza P, dkk. Morphometry of dermal nerve fibers in human skin. Neurology. 2011:77:242-9.

16. Casellini CM, Vinik AI. Clinical manifestations and current treatment options for diabetic neuropathies. Endocr Pract. 2007;13(5):550-66.

17. Bansal D, Gudala K, Muthyala H, Esam HP, Nayakallu R, Bhansali A. Prevalence and risk factors of development of peripheral diabetic neuropathy in type 2 diabetes mellitus in a tertiary care setting. J Diabetes Invest. 2015;5(6):714-21. 